\title{
Assessment of the Impact of COVID-19 on the Educational Activity in Russia
}

\author{
Goreeva N.M. ${ }^{1}$ Demidova L.N. ${ }^{2}$ Savchina O.V. ${ }^{3, *}$
}

\author{
${ }^{1}$ Kaluga branch Federal State Budgetary Educational Institution of Higher Education "Russian Timiryazev State \\ Agrarian University”, Kaluga 248007, Russia \\ ${ }^{2}$ Plekhanov Russian University of Economics, Moscow 117997, Russia. \\ ${ }^{3}$ Peoples' Friendship University of Russia (RUDN University), Moscow 117437, Russia \\ * Corresponding author. Email: savchina-ov@ rudn.ru
}

\begin{abstract}
The number of schoolchildren and students, as well as teachers and university professors who do not attend schools and universities due to the outbreak of the coronavirus infection (COVID-19) is growing significantly. Governments around the world, including Russia, were forced to decide to close their educational institutions in order to contain the global COVID-19 pandemic. However, the closure of schools and universities across the country has led millions of students to switch from traditional learning to distance learning. In this regard, the authors attempted to assess the impact of the coronavirus pandemic on education in Russia. The study was conducted using nonparametric methods to assess the degree of correlation between the transition to distance learning during the pandemic and the effectiveness of training in higher education institutions. The study showed that the major Russian universities have coped with the problem of distance learning by using information services and training platforms.
\end{abstract}

Keywords: education, economy, coronavirus pandemic, COVID-19, distance learning

\section{INTRODUCTION}

Higher education around the world is experiencing problems due to the epidemiological situation associated with the coronavirus infection - COVID-19. Most states in these circumstances provide assistance and support only for the school education. Higher and special education are forced to solve their problems with distance learning on their own. This situation exists developing not only in Russia, but also in America and Europe. In this regard, the study of the impact of COVID-19 on education has become a particularly relevant issue that many Russian scientists consider in their works $[7,8]$. According to the Director of the research center for monitoring and statistics of education FIRO Ranepa M. L. Agranovich, despite the negative consequences of the COVID-19 coronavirus outbreak, the pandemic still gave a number of opportunities and understanding that in the modern world it is necessary to be able to overcome the digital divide and learn to resist various threats. He also believes that bridging the digital divide can ensure sustainability in the most important sector of human development - education [1]. And according to I. Frumin, research Director of the HSE Institute of education, it is worth paying attention to what happened to learning in the context of the educational results of schoolchildren and students over the long months of physical distance. He believes that despite the fact that maximum efforts were made in Russia to quickly organize distance learning for schoolchildren and students, this did not allow them to make the learning process as effective as in the traditional educational process [2].

According to D. Melnik, head of the Research group at the center for educational transformation of the Moscow school of management SKOLKOVO, there are three ways to look at the consequences of the current crisis in education for both the Russian and global higher education systems. The first way, in her opinion, is that COVID-19 forced the transition to online. The second way, in her opinion, is that the pandemic will allow us to assess the level of readiness of schools and universities for the shock itself. And she believes that universities, despite their historical stability, are ill-prepared for such crises. And the third way to assess the consequences of the current crisis is that now is the time to diagnose higher education, that is, to identify the problems that have arisen [3].

At the same time, the World Bank's head of educational projects in Russia, T. Schmis, believes that the consequences of the pandemic will have a long-term impact on education. In his speech during the online webinar "education under COVID-19: problems, solutions, perspectives, research", organized by the HSE and the World Bank, he said that the coronavirus pandemic has led to a double crisis, namely, the educational crisis associated with the closure of schools and universities, and the general economic crisis that also affects the education sector [6].

As a result, the educational activities of most higher education institutions during the coronavirus pandemic received a "magic kick". The situation is aggravated by the fact that over the past decades (after the Millennium), the 
education system has undergone significant changes not in the best direction. On the one hand, the transition to international standards makes it possible to assume an expansion of the borders of employment of graduates; on the other hand, a serious "economization" of higher education has led to a drop in the quality of trained specialists, the demand for which is not growing at the desired pace. In the context of the pandemic, the situation was complicated by the fact that in the pursuit of stability of the student population, a formal approach to the educational process was strengthened on the part of both students and teachers [4].

\section{METHODOLOGY}

This study is based on a survey of full-time students of the Russian universities conducted by the CESSI (By the Institute for Comparative Social Research) in may 2020 a part of the international student survey on coronavirus (MOSC). The survey involved 2,600 respondents in an online form.

Participants answered questions about the time spent on distance learning, the degree of satisfaction with the work of teachers and their readiness for this form of training, synchronization of the material and technical base for this format of training, etc.

The authors ' research involves the use of nonparametric methods to assess the degree of correlation between the transition to distance learning during the pandemic and the effectiveness of training in higher education institutions. In this article, the results of the survey of students are divided into 2 alternative groups - before and after switching to distance learning using "tetrachoric indicators" or conjugacy tables. Nonparametric methods take into account the direction of changes in feature values, but do not depend on the intensity of their fluctuations. There are quite a lot of criteria for detecting such significance: the classical $\chi 2$ criterion and the Wulf G-criterion, etc. However, their use only allows us to evaluate the relationship at the hypothetical level. Therefore, the paper uses the "first" criteria, which give a preliminary assessment of the possibility of a relationship between variables to put forward a true null hypothesis. These criteria include the Association coefficient, the Yule colligation coefficient, the contingent coefficient, and the fast link evaluation criterion [5].

The classical criterion $\chi 2$ was used by the authors to evaluate the hypothesis of the presence or absence of a relationship between the questionnaire questions before and after self-isolation.

\section{RESULTS}

According to an international survey of students about COVID-19, it can be concluded that the amount of time spent on training sessions with a teacher has sharply decreased. There is a real opportunity to avoid them altogether (table 1).

Table 1 How many hours per week did students spend on the following activities

\begin{tabular}{|c|c|c|c|c|}
\hline Time & \multicolumn{2}{|c|}{$\begin{array}{l}\text { Before the } \\
\text { COVID-19 } \\
\text { pandemic }\end{array}$} & \multicolumn{2}{|c|}{ For the last week } \\
\hline \multicolumn{5}{|c|}{ for training sessions with a teacher } \\
\hline Nary & \multicolumn{2}{|l|}{$7 \%$} & \multicolumn{2}{|l|}{$74 \%$} \\
\hline 1-9 hours & \multicolumn{2}{|c|}{$12 \%$} & \multicolumn{2}{|l|}{$9 \%$} \\
\hline 10-19 hours & \multicolumn{2}{|l|}{$16 \%$} & \multicolumn{2}{|l|}{$5 \%$} \\
\hline 20-29 hours & $24 \%$ & 93 & \multicolumn{2}{|l|}{$4 \%$} \\
\hline 30-39 hours & $22 \%$ & & \multicolumn{2}{|l|}{$3 \%$} \\
\hline $\begin{array}{l}40 \text { hours or } \\
\text { more }\end{array}$ & $19 \%$ & & \multicolumn{2}{|l|}{$4 \%$} \\
\hline \multicolumn{5}{|c|}{ for online training sessions } \\
\hline Nary & \multicolumn{2}{|c|}{$52 \%$} & \multicolumn{2}{|l|}{$15 \%$} \\
\hline 1-9 hours & \multicolumn{2}{|l|}{$30 \%$} & \multicolumn{2}{|l|}{$32 \%$} \\
\hline 10-19 hours & \multicolumn{2}{|l|}{$8 \%$} & \multicolumn{2}{|l|}{$21 \%$} \\
\hline 20-29 hours & $4 \%$ & & \multicolumn{2}{|l|}{$15 \%$} \\
\hline 30-39 hours & $3 \%$ & 18 & \multicolumn{2}{|l|}{$9 \%$} \\
\hline $\begin{array}{l}40 \text { hours or } \\
\text { more }\end{array}$ & $3 \%$ & & \multicolumn{2}{|l|}{$10 \%$} \\
\hline \multicolumn{5}{|c|}{ for independent training } \\
\hline Nary & \multicolumn{2}{|c|}{$2 \%$} & \multicolumn{2}{|l|}{$4 \%$} \\
\hline $1-9$ hours & $25 \%$ & & $18 \%$ & \\
\hline 10-19 hours & $29 \%$ & 74 & $19 \%$ & 54 \\
\hline 20-29 hours & \multicolumn{2}{|l|}{$20 \%$} & \multicolumn{2}{|l|}{$17 \%$} \\
\hline 30-39 hours & $10 \%$ & & $13 \%$ & 42 \\
\hline $\begin{array}{l}40 \text { hours or } \\
\text { more }\end{array}$ & $14 \%$ & 24 & $29 \%$ & \\
\hline \multicolumn{5}{|c|}{ for a paid job } \\
\hline Nary & $58 \%$ & & $71 \%$ & \\
\hline 1-9 hours & $13 \%$ & 71 & $10 \%$ & 81 \\
\hline 10-19 hours & \multicolumn{2}{|l|}{$8 \%$} & \multicolumn{2}{|l|}{$6 \%$} \\
\hline 20-29 hours & \multicolumn{2}{|l|}{$7 \%$} & \multicolumn{2}{|l|}{$4 \%$} \\
\hline 30-39 hours & $4 \%$ & & $3 \%$ & \\
\hline $\begin{array}{l}40 \text { hours or } \\
\text { more }\end{array}$ & $10 \%$ & & $6 \%$ & \\
\hline
\end{tabular}

*Authors ' calculations based on the international student survey on coronavirus (MOSC)

Thus, a survey of students in Russia showed that the amount of time spent on online classes in the mode from 1 to 9 hours varies slightly (by 2 percentage points ( p. p.)), that is, about 6 pairs a week, the student was engaged in finalizing the material in addition to the hours of work with the teacher, and now he is forced to study subjects online as much as possible. This in turn leads to a reduction in responsibility. So, the share of selfemployment time (1-29 hours) before the pandemic was $74 \%$ per week, and during its period it decreased by 20 
p.p. At the same time, the independent load of 40 or more hours is significantly increased. However, we can assume that this situation is an exception to the rule, and is inherent in a small contingent of students. The vast majority of students, realizing that the University is not interested in their expulsion under the current conditions, will not study effectively in advance.

The authors 'assessment of respondents' responses on the time spent (labor intensity of training) and the problems created by the situation with COVID-19 using nonparametric methods revealed a direct moderate relationship between them (table 2).

Table 2 Grouping Classification of the respondent responses to the international student survey on coronavirus (MOSC)

\begin{tabular}{|l|l|l|l|}
\hline $\begin{array}{l}\text { Students } \\
\text { opinion on the } \\
\text { organization } \\
\text { of the } \\
\text { learning } \\
\text { process }\end{array}$ & $\begin{array}{l}\text { Respondent responses } \\
\text { Total } \\
\text { and } \\
\text { rather } \\
\text { agree }\end{array}$ & $\begin{array}{l}\text { Totally } \\
\text { disagree } \\
\text { and rather } \\
\text { disagree }\end{array}$ & \\
\hline $\begin{array}{l}\text { Significant } \\
\text { increase in } \\
\text { training load }\end{array}$ & 68 & 19 & 87 \\
\hline $\begin{array}{l}\text { The University } \\
\text { has someone } \\
\text { to discuss the } \\
\text { problematic } \\
\text { situation with } \\
\text { Covid-19 }\end{array}$ & 31 & 33 & 64 \\
\hline $\begin{array}{l}\text { Total } \\
\text { responses }\end{array}$ & 99 & 52 & 151 \\
\hline
\end{tabular}

*Authors ' calculations based on the international student survey on coronavirus (MOSC)

The coefficients of the Association of D. Yul and the contingent calculated from the conjugacy table showed a significant relationship between the questions to respondents and their answers on the impact of Covid-19 on their training system:

$$
\begin{aligned}
& \mathrm{K}_{\mathrm{a}}=\frac{n_{11} \cdot n_{22}-n_{21} n_{12}}{n_{11} \cdot n_{22}+n_{21} \cdot n_{12}}=\frac{68 \cdot 33-31 \cdot 19}{68 \cdot 33+31 \cdot 19}=0,58 \\
& \mathrm{~K}_{\mathrm{K}}=\frac{n_{11} \cdot n_{22}-n_{21} n_{12}}{\sqrt{\left(n_{11}+n_{12}\right)-\left(n_{21}+n_{22}\right)-\left(n_{11}+n_{21}\right)-\left(n_{12}+n_{22}\right)}}= \\
& \frac{68 \cdot 93-31 \cdot 19}{\sqrt{97-64 \cdot 99 \cdot 52}}=0,309
\end{aligned}
$$

The Yule colligation coefficient $\mathrm{Y}$ was 0.32 , the average value between the Association coefficient and the contingent coefficient:

$Y=\frac{\sqrt{n_{11} \cdot n_{22}}-\sqrt{n_{21} \cdot n_{12}}}{\sqrt{n_{11} \cdot n_{22}}+\sqrt{n_{21} \cdot n_{12}}}=\frac{\sqrt{68 \cdot-38}-\sqrt{81 \cdot 19}}{\sqrt{68 \cdot \sqrt{2}}+\sqrt{81 \cdot 19}}=0,32$.

Thus, the nonparametric assessment showed a direct relationship between the increase in time and the problems of switching to distance learning.

Not only the higher education system, but also the contingent of students were not ready for such independence in distance learning, a high degree of self- awareness and optimization of the effectiveness of the learning system. Working with a teacher during training before self-isolation was the easiest way to get and practice the knowledge gained. Students could not quickly rebuild their minds and organize the learning process without tutor support.

Thus, the grouping of students surveyed showed a direct relationship between the amount of work with teachers before and during the Covid-19 pandemic (table 3).

Table 3 Grouping Classification of respondents by the complexity of training with a teacher before and during self-isolation

\begin{tabular}{|l|c|c|c|}
\hline $\begin{array}{l}\text { Students ' } \\
\text { opinion on } \\
\text { the amount of } \\
\text { time spent } \\
\text { studying with } \\
\text { a teacher }\end{array}$ & $\begin{array}{c}\text { Respondent responses } \\
\text { self- } \\
\text { isolation }\end{array}$ & $\begin{array}{c}\text { Total } \\
\text { Delf- } \\
\text { isolation } \\
\text { responses }\end{array}$ & \\
\hline Nary per & 7 & 74 & 81 \\
\hline $\begin{array}{l}\text { From 1 to 19 } \\
\text { hours poek } \\
\text { week }\end{array}$ & 28 & 14 & 42 \\
\hline $\begin{array}{l}\text { More than 20 } \\
\text { hours a week }\end{array}$ & 65 & 11 & 76 \\
\hline $\begin{array}{l}\text { Total } \\
\text { responses }\end{array}$ & 100 & 99 & 199 \\
\hline
\end{tabular}

*Authors ' calculations based on the international student survey on coronavirus (MOSC)

The calculated value of the $\chi^{2}-$ criterion with the number of degrees of freedom equal to 2 showed that $\chi 2$ is 98.452 , the table value at the significance level $\mathrm{p}=0.01$ is 9.21 . Thus, the relationship between the factorial and effective features is statistically significant at the significance level $\mathrm{p}<0.01$.

The value of $\chi^{2}$ calculated from a similar conjugacy table for the time that students spend on independent training before and during distance learning was 35.980 , with its table value of 9.21 (with a significance level of $\mathrm{p}=0.01$ ), showed the presence of a statistically significant relationship.

Thus, there is a direct correlation between the time spent on training and preparation for classes in distance and fulltime education.

\section{DISCUSSION OF RESULTS}

The quality of education, according to the survey, has decreased, leading to an increase in indifference to the results of the learning process, aggravation of stressful situations, and increased concern about the success of the school year. 


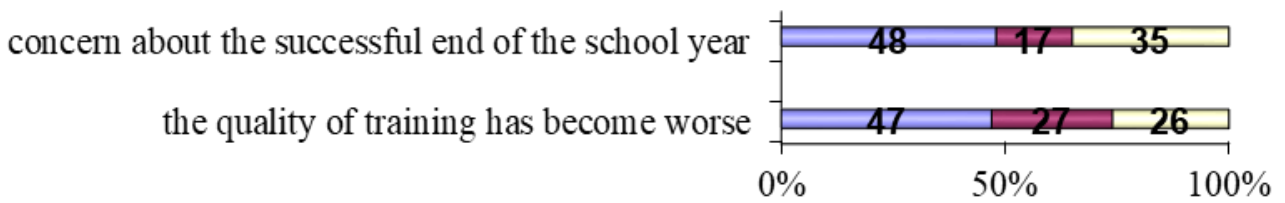

\begin{abstract}
$\square$ fully agree and rather agree
Figure 1 Students ' opinion on the quality of training and its success

Moreover, only $47-48 \%$ of students are concerned about the quality of their knowledge. for the rest of the students, this situation is a reason for the avoiding of the educational process.
\end{abstract}

$\square$ neither Yes nor No

Drather and completely disagree

*Authors ' calculations based on the international student survey on coronavirus (MOSC)

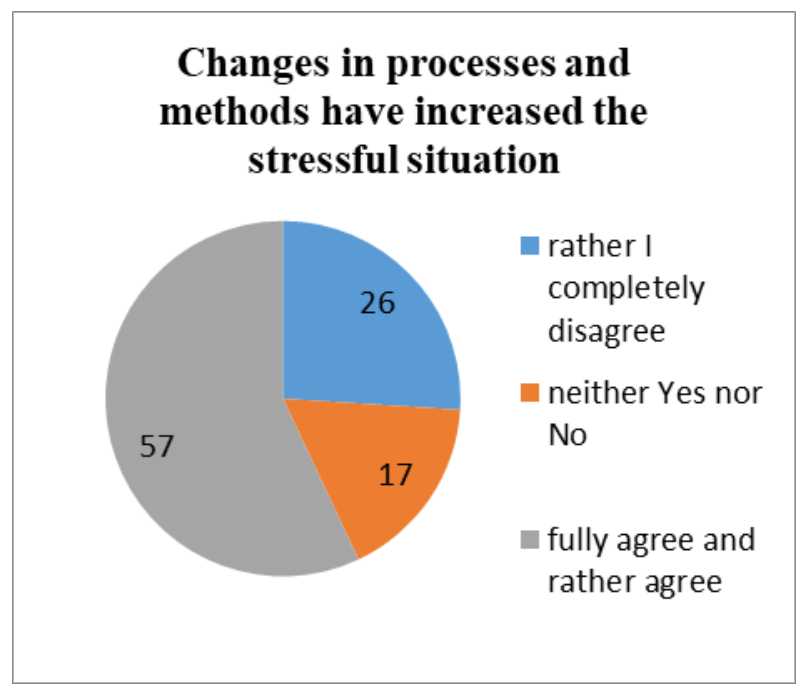

Not regulated the mechanism of distance education and sometimes the lack of basic electronic environment education (not so much as on the part of the University, but on the student one) led to a reduction in the understanding of the subject of the training course.

\section{I began to understand less what I should do for different courses}

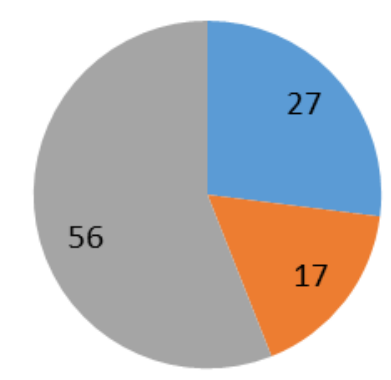

rather I completely disagree

neither Yes nor No

fully agree and rather agree

Figure 2 Students ' view on the presence of stress and understanding of the subject of the discipline *Authors ' calculations based on the international student survey on coronavirus (MOSC)

Thus, most students experience a stressful situation from the change of training, spend more time preparing for classes. However, the student community has become more differentiated: either students spend more time preparing for classes, or they no longer consider it necessary to spend their free time studying at all.

\section{CONCLUSION}

"Challenges of modern life" require a comprehensive approach to solving the problems that have arisen [9]. On the one hand, it is expanding the online capabilities of educational institutions, and on the other hand, improving the material and technical base of online communication in the regions. The availability of Internet services in all regions of the country, their cheapness, and protection from third-party inclusions will improve the situation with the quality of educational services [10].
Most major universities have coped with the problem of distance learning on a large scale using information services and training platforms. The digital environment made it possible to combine the effectiveness of traditional classroom training with IT training services and interaction between students and teachers using elements of individual and separate forms.

\section{REFERENCES}

[1] Agranovich M. L., Grineva A. "Organization of education in the context of the pandemic. Practice of the OECD countries". Monitoring the economic situation in Russia :trends and challenges of socioeconomic development, 2020; № 9 (111): 134-150.

[2] Vladimir A. Zernov, Algirdas YU. Manyushis, Andrey YU. Valyavsky, Nadezhda V. Uchevatkina 
«Educational space of Russia aftera pandemia: challenges, lessons,trends». Scientific the works of the VEO of Russia. A special issue of «Scientific works of the Free Economic Society of Russia» is co-published by the Free Economic Society of Russia, the Russian Academy of Sciences and the International Union of Economists Volume № 3 (223) 2020 304-323. DOI: $10.38197 / 2072-2060-2020-223-3-304-322$

[3] Indicators of education 2020: statistical book / N.V. Bondarenko, D.R. Borodina, L.M. Gohberg et al.; National Research University "Higher School of Economics". - Moscow. NRU HSE Publishing House, 2020. URL:

https://issek.hse.ru/mirror/pubs/share/352549981.pdf

[4] Klyagin A.V., Abalmasova E. S., Garev K. V., Gruzdev I. A., Egorov A. A., Zakharova U. S., Kalinin R. G., Kamaldinova L. R., Karlov I. A., Korneeva I. E., Makarieva A. Yu., Minaeva E. A., Platonova D. P., Semenova T. V., Skokova Yu .A., Terentyev E. A., Frumin I. D., Shvindt A. N., Shibanova E. Yu. Storm of the first weeks: how higher education took a step the reality of a pandemic. National research University higher school of Economics, Institute of education. Moscow: HIGHER school of Economics, (Modern Analytics of education. № 6 (36)) (2020) Pp.112.

[5] A. N. Antamoshkin, O. A. Bakaeva. "Comparative analysis of the "first" criteria for identifying the relationship between qualitative variables". Bulletin of the Siberian state aerospace University. academician M. F. Reshetnev, (2011) (4) 4-7.

[6] Moskovskij akademicheskij jekonomicheskij forum. 14 maja - 31 maja 2020 goda. «Postpandemicheskij mir i Rossija: novaja real'nost'?». Rezhim dostupa: URL: https://maef.veorus.ru/

[7] Polbin A.V., Sinelnikov-Murylev S.G., Trunin P.V. The economic crisis of 2020: Reasons, policies to deal with and further development of the Russian economy. Voprosy Ekonomiki. 2020;(6):5-21. (In Russ.) https://doi.org/10.32609/0042-8736-2020-6-5-21

[8] Kuranov G.O., Luk’yanenko R.F. Quality and Factors of Economic Development: Matters of Evaluation and Analysis. Voprosy statistiki. 2020;27(3):26-44. (In Russ.) https://doi.org/10.34023/2313-6383-2020-27-3-26-44

[9] Zvonova E.A. Transformation of the world economy and the pandemic. Ekonomika. Nalogi. Pravo = Economics, taxes \& law. 2020;13(4):6-19. (In Russ.). DOI: $10.26794 / 1999-849 X$ 2020-13-4-6-19
[10] Gruzina Y.M., Sorokin D.D., Shtanova K.A. The Role of science and Education in the Development of Human Capital. Humanities and Social Sciences. Bulletin of the Financial University. 2020;10(2):59-65. (In Russ.) https://doi.org/10.26794/2226-7867-2020-102-59-65 